\title{
Penerapan Model Pembelajaran Thinking Aloud Pair Problem Solving (TAPPS) untuk Meningkatkan Hasil Belajar Fisika pada Siswa Kelas XI IPA SMA Negeri 8 Palu
}

\author{
Ratnasari, Muhammad Ali, dan Nurasyah Dewi Napitupulu \\ Email: Ratnasari_phynopank@yahoo.co.id \\ Program Studi Pendidikan Fisika, Jurusan Pendidikan MIPA, Universitas Tadulako \\ Jl. Soekarno Hatta KM. 9 Kampus Bumi Tadulako Tondo Palu - Sulawesi Tengah
}

\begin{abstract}
Abstrak - Pembelajaran Fisika di SMA Negeri 8 Palu merupakan pembelajaran yang umumnya didominasi oleh guru sehingga menyebabkan rendahnya hasil belajar siswa serta kurangnya motivasi belajar siswa terhadap mata pelajaran fisika. Tujuan penelitian ini untuk meningkatkan hasil belajar fisika melalui penerapan model pembelajaran Thinking Aloud Pair Problem Solving (TAPPS). Penelitian ini merupakan penelitian tindakan kelas (PTK) pada siswa kelas XI IPA SMA Negeri 8 Palu yang berjumlah 22 orang siswa. Tindakan kelas dilakukan dalam dua siklus dengan materi usaha dan energi. Data dikumpulkan melalui lembar observasi dari aktifitas guru dan aktifitas siswa, serta tes hasil tindakan. Hasil penelitian menunjukkan bahwa aktifitas guru dan siswa mengalami peningkatan yang signifikan dari siklus I ke siklus II dan berada dalam kategori baik dan sangat baik. Berdasarkan analisis hasil belajar diperoleh hasil belajar siswa siklus I ke siklus II mengalami peningkatan, dengan nilai daya serap klasikal siklus I sebesar 75,15\%, dan siklus II sebesar $89,09 \%$ meningkat sebesar $15,64 \%$. Untuk ketuntasan belajar klasikal meningkat sebesar $14,99 \%$ dengan nilai ketuntasan klasikal siklus I adalah $77,27 \%$ dan siklus II sebesar $90,90 \%$. Berdasarkan indikator keberhasilan yakni apabila persentase daya serap klasikal 80\% dan ketuntasan klasikal 80\%, disimpulkan bahwa penerapan model pembelajaran Thinking Aloud Pair Problem Solving (TAPPS) dapat meningkatkan hasil belajar fisika siswa kelas XI IPA SMA Negeri 8 Palu.
\end{abstract}

Kata Kunci: Thinking Aloud Pair Problem Solving, Hasil Belajar

\section{PENDAHULUAN}

Proses belajar mengajar merupakan inti dari kegiatan pendidikan di sekolah dan suatu proses membangun pengetahuan yang melibatkan interaksi antara pengajar dan peserta didik serta materi yang saling menguntungkan. Dahar dan Siregar [1] menyatakan bahwa guru juga berperan dalam mengelola proses belajar mengajar dengan menerapkan keterampilan intelektual, menjelaskan masalah dan memecahkannya. Dengan demikian, keberhasilan belajar siswa selain ditentukan oleh kemampuan kognitif dan usaha belajarnya, juga dipengaruhi oleh model belajar yang diterapkan oleh guru dalam proses pembelajaran.

Pelaksanaan pembelajaran di kelas merupakan salah satu tugas utama guru. Pembelajaran di kelas masih sering ditemui adanya kecenderungan meminimalkan keterlibatan siswa. Dimana siswa lebih bersifat pasif sehingga mereka lebih banyak menunggu sajian guru daripada mencari dan menemukan sendiri pengetahuan, keterampilan atau sikap yang mereka butuhkan. Kondisi ini tidak menumbuhkembangkan aspek kemampuan dan aktifitas siswa yang diharapkan, bahkan dapat berakibat membosankan pada diri siswa untuk menerima pelajaran. Siswa hanya dianggap sebagai pendengar saja tanpa melibatkan mereka dalam pembelajaran. Kondisi ini akan berdampak pada keaktifan dan motivasi siswa dalam proses belajar mengajar, bahkan mengakibatkan rendahnya hasil belajar.

Berdasarkan hasil observasi awal di SMA Negeri 8 Palu, diperoleh bahwa kriteria ketuntasan minimal (KKM) untuk mata pelajaran fisika adalah 70\%. Akan tetapi hasil yang diperoleh tidak mencapai KKM. Hal ini disebabkan oleh aktifitas siswa dalam belajar fisika hanya sebatas mendengar dan melihat guru dalam menjelaskan materi ajar, sehingga antar siswa tidak ada interaksi. Proses pembelajaran 
masih bersifat teacher centered/oriented. Akibatnya adalah nilai ulangan semester siswa kelas XI IPA untuk mata pelajaran fisika, seperti terlihat pada Tabel 1.

TABEL 1. NILAI RATA-RATA ULANGAN SEMESTER FISIKA KELAS XI IPA FISIKA SMA NEGERI 8 PALU TAHUN

AJARAN 2011/2012

\begin{tabular}{|c|c|c|}
\hline \multirow{2}{*}{ No. } & \multirow{2}{*}{ Semester } & Nilai Rata-Rata Kelas \\
\cline { 3 - 3 } & & Kelas XI IPA \\
\hline 1. & Ganjil & 50.0 \\
2. & Genap & 56,5 \\
\hline
\end{tabular}

Sumber : SMA Negeri 8 Palu

Berdasarkan tabel di atas terlihat perolehan nilai siswa kelas XI IPA yang dicapai pada semester ganjil dan genap tahun ajaran 2011/2012 tidak mencapai KKM sekolah sebesar 70\%. Berbagai usaha telah diupayakan untuk meningkatkan hasil belajar siswa antara lain pemberian tugas-tugas dan memberikan remedial pada siswa yang mengalami kesulitan belajar.

Model pembelajaran Thinking Aloud Pair Problem Solving (TAPPS) dilakukan dengan mengelompokkan siswa secara berpasang-pasangan untuk menyelesaikan permasalahan yang terdapat dalam kehidupan sehari-hari. Setiap kelompok terdiri dari dua orang siswa yang diberi peranan yang berbeda satu sama lain pada setiap masalah. Satu orang siswa menjadi pemecah masalah atau problem solver (PS) dan satu orang siswa lagi menjadi pendengar atau listener ( $L$ ). Setiap kelompok mempunyai tugas masing-masing yang akan mengikuti aturan tertentU [4]. Menurut Kyungmoon Jeon [3] model Thinking Aloud Pair Problem Solving (TAPPS) yang dikembangkan oleh Arthur Whimbey dapat memantau siswa dalam penggunaan strategi pemecahan masalah mereka. Siswa bekerja menyelesaikan masalah, dimana salah satu siswa memecahkan masalah sementara yang lainnya mendengarkan. Dengan demikian, model ini dapat membantu siswa mengamati dan memahami proses berpikir mereka sendiri dan temannya.

Berdasarkan uraian di atas dirumuskan hipotesis bahwa penerapan model pembelajaran Thinking
Aloud pair Problem Solving (TAPPS) dapat meningkatkan hasil belajar fisika pada siswa kelas XI IPA SMA Negeri 8 Palu.

\section{METODOLOGI PENELITIAN}

Penelitian ini dilaksanakan di SMA Negeri 8 Palu, yang dilaksanakan dalam 2 siklus, masing-masing siklus melalui tahap perencanaan, pelaksanaan, observasi dan refleksi. Tahapan ini mengacu pada model Kurt Lewin yang dikembangkan oleh Kemmis dan Mc. Taggart [2].

Subyek penelitian ini adalah seluruh siswa kelas XI IPA SMA Negeri 8 Palu yang terdaftar pada semester ganjil tahun ajaran 2013/2014 yang berjumlah 22 orang siswa. Metode pengumpulan data pada penelitian ini, meliputi observasi menggunakan lembar observasi dan tes hasil belajar fisika. Faktor-faktor yang diteliti adalah aktifitas guru, aktifitas siswa, afektif siswa, dan hasil belajar siswa. Analisis data terbagi menjadi dua kelompok yaitu analisa data kuantitatif dan data kualitatif. Analisis data kuantitatif dilakukan dengan menghitung KBK dan DSK. kriteria ketuntasan ditetapkan dengan KKM 80\%.

\section{HASIL DAN PEMBAHASAN}

Data hasil analisis penilaian observasi aktifitas guru siklus I dan siklus II dapat dilihat pada Tabel 2. TABEL 2 HASIL ANALISIS OBSERVASI AKTIFITAS GURU SIKLUS I DAN SIKLUS II

\begin{tabular}{|c|c|c|c|}
\hline Siklus & Pertemuan & $\begin{array}{c}\text { Rerata } \\
\text { Aktifitas } \\
\text { Guru }(\%)\end{array}$ & Kategori \\
\hline \multirow{2}{*}{ Satu } & Pertama & 78.18 & Baik \\
\cline { 2 - 4 } & Kedua & 83.63 & Baik \\
\hline \multirow{2}{*}{ Dua } & Pertama & 85.45 & Sangat Baik \\
\cline { 2 - 4 } & Kedua & 89.09 & Sangat Baik \\
\hline
\end{tabular}

Tabel 2 menunjukkan bahwa persentase ratarata aktifitas guru siklus I pada pertemuan pertama dan pertemuan kedua berada pada kategori baik. Pada siklus II, persentase rata-rata aktifitas guru pada pertemuan pertama dan pertemuan kedua berada dalam kategori sangat baik.

Data hasil analisis observasi aktifitas siswa siklus I dan siklus II dapat dilihat pada Tabel 3. 
TABEL 3 HASIL ANALISIS OBSERVASI AKTIFITAS SISWA SIKLUS I DAN SIKLUS II

\begin{tabular}{|c|c|c|c|}
\hline Siklus & Pertemuan & $\begin{array}{c}\text { Rerata Aktifitas } \\
\text { Siswa }(\%)\end{array}$ & Kategori \\
\hline \multirow{2}{*}{ Satu } & Pertama & 75.38 & Baik \\
\cline { 2 - 4 } & Kedua & 78.46 & Baik \\
\hline \multirow{2}{*}{ Dua } & Pertama & 80.00 & Baik \\
\cline { 2 - 4 } & Kedua & 84.61 & Baik \\
\hline
\end{tabular}

Tabel 3 menunjukkan bahwa persentase ratarata aktifitas siswa siklus I dan siklus II untuk pertemuan pertama dan pertemuan kedua berada pada kategori baik.

Hasil analisis observasi aktifitas guru dan aktifitas siswa pada siklus I dan siklus II, dapat dilihat pada gambar 1 .

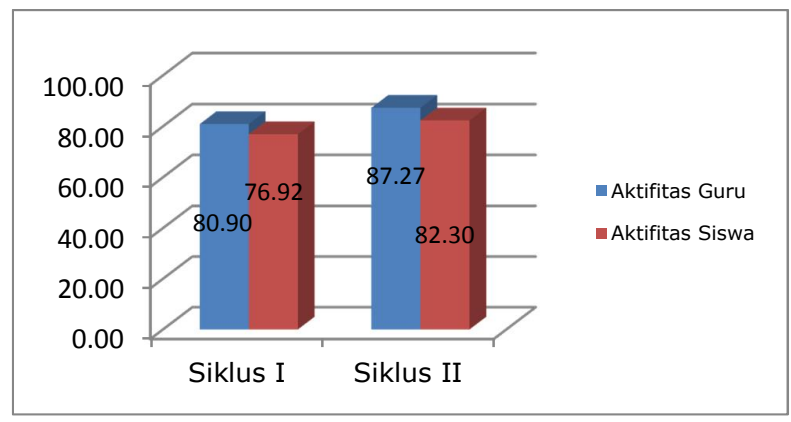

Gambar 1 Grafik Analisis Aktifitas Guru dan Siswa pada Siklus I dan Siklus II

Selain terjadi peningkatan aktifitas guru dan siswa, penerapan model pembelajaran Thinking Aloud Pair Problem Solving (TAPPS) ini juga dapat meningkatkan penilaian afektif siswa (Gambar 2). dan data hasil analisis penilaian afektif siswa siklus I dan siklus II dapat dilihat pada Tabel 4.

TABEL 4 HASIL ANALISIS PENILAIAN AFEKTIF SISWA SIKLUS I DAN SIKLUS II

\begin{tabular}{|c|c|c|c|}
\hline \multirow{2}{*}{ Siklus } & Pertemuan & $\begin{array}{c}\text { Rerata Afektif } \\
\text { Siswa }(\%)\end{array}$ & Kategori \\
\hline \multirow{2}{*}{ Satu } & Pertama & 75.27 & Baik \\
\cline { 2 - 4 } & Kedua & 78.18 & Baik \\
\hline \multirow{2}{*}{ Dua } & Pertama & 78.90 & Baik \\
\cline { 2 - 4 } & Kedua & 82.72 & Baik \\
\hline
\end{tabular}

Dari Tabel 4 diketahui bahwa persentase nilai rata-rata keberhasilan afektif siswa siklus I dan siklus II pada pertemuan pertama dan kedua berada pada kategori baik.

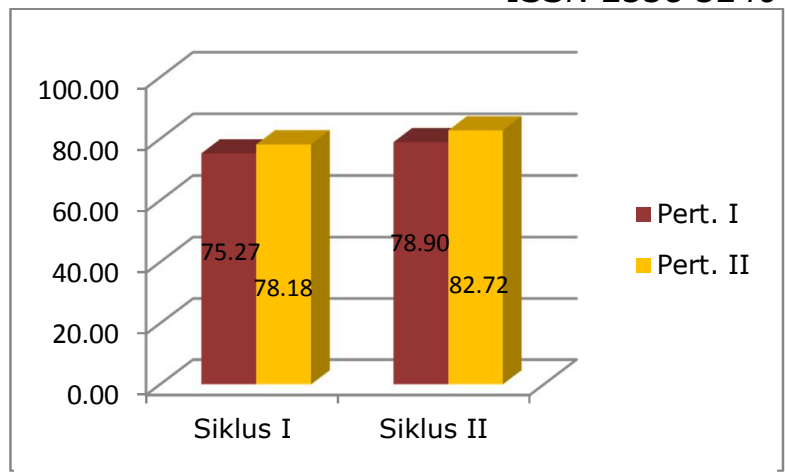

Gambar 2 Grafik Penilaian Afektif Siswa pada Siklus I dan Siklus II

Berdasarkan gambar 2, Grafik penilaian afektif pada siswa setiap pertemuan untuk siklus I dan sikus II terjadi peningkatan. Hal ini disebabkan karena penekanan guru kepada siswa untuk setiap pertemuan sangat berpengaruh terhadap keafektifan siswa dalam kegiatan belajar mengajar (KBM).

Data analisis hasil belajar siswa siklus I dan siklus II. Serta grafik ketuntasan belajar klasiskal (KBK) dan daya serap klasikal (KBK).

TABEL 5 HASIL BELAJAR SISWA SIKLUS I DAN SIKLUS II

\begin{tabular}{|c|l|c|c|}
\hline \multirow{2}{*}{ No } & \multirow{2}{*}{ Aspek Perolehan } & \multicolumn{2}{|c|}{ Hasil } \\
\cline { 3 - 4 } & & Siklus I & Siklus II \\
\hline 1. & Skor maksimal & 15 & 15 \\
\hline 3 & Skor tertinggi & 14 & 15 \\
\hline 4 & $\begin{array}{l}\text { Banyaknya siswa } \\
\text { yang memperoleh } \\
\text { skor tertinggi }\end{array}$ & 3 orang & 1 orang \\
\hline 5 & $\begin{array}{l}\text { Skor terendah } \\
\text { yang memperoleh } \\
\text { skor terendah }\end{array}$ & 1 orang & 2 orang \\
\hline 6 & $\begin{array}{l}\text { Banyaknya siswa } \\
\text { yang tuntas }\end{array}$ & 17 orang & 20 orang \\
\hline 7 & $\begin{array}{l}\text { Banyaknya siswa } \\
\text { yang belum tuntas }\end{array}$ & 5 orang & 2 orang \\
\hline 8 & $\begin{array}{l}\text { Persentase daya } \\
\text { serap klasikal }\end{array}$ & $\begin{array}{l}\text { Persentase } \\
\text { ketuntasan } \\
\text { belajar klasikal }\end{array}$ & $75.15 \%$ \\
\hline
\end{tabular}




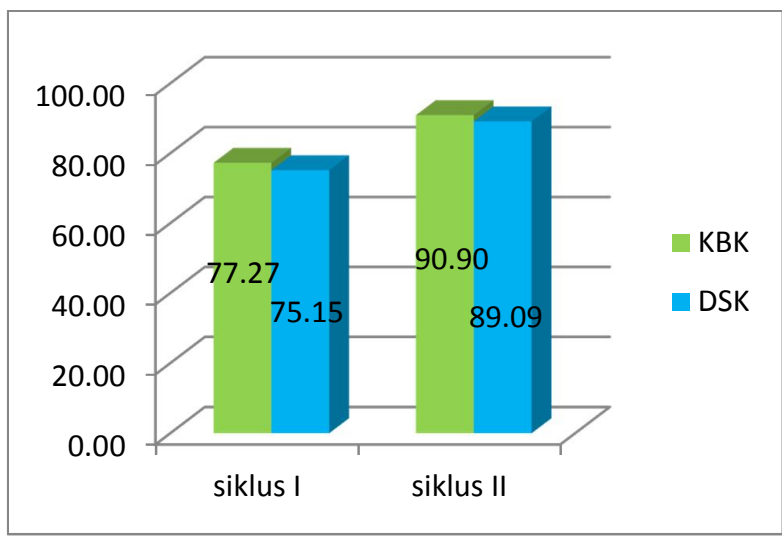

Gambar 3 Grafik Analisis KBK dan DSK Siklus I dan Siklus II

Berdasarkan hasil belajar siklus I, diperoleh aktifitas guru pada pertemuan pertama sebesar $78,18 \%$ menjadi $83,63 \%$ pertemuan kedua, sedangkan untuk aktifitas siswa sebesar 75,38\% pada pertemuan pertama menjadi $78,46 \%$ pertemuan kedua, masing-masing berada dalam kategori baik. Pada siklus II diperoleh hasil observasi aktifitas guru pada pertemuan pertama sebesar $85,45 \%$ menjadi $89,09 \%$ pada pertemuan kedua, berada dalam kategori sangat baik. Dan untuk aktifitas siswa sebesar $80,00 \%$ pada pertemuan pertama menjadi $84,61 \%$ pada pertemuan kedua, berada dalam kategori baik. Dengan kata lain, dari siklus I ke siklus II, aktifitas guru meningkat sebesar $7,29 \%$, dan aktifitas siswa meningkat sebesar $6,53 \%$. Hal ini disebabkan karena guru sangat berperan pada setiap tahap pembelajaran sehingga berpengaruh terhadap aktifitas siswa. Guru berperan membimbing siswa mengungkapkan ide-ide mereka dan membangun konsep siswa yang sebenarnya melalui pembelajaran serta mendorong siswa agar lebih aktif dalam melakukan kegiatan pembelajaran.

Berdasarkan analisis tes hasil belajar yang dilakukan pada siklus I dan siklus II, diketahui bahwa hasil belajar fisika siswa kelas XI IPA SMA Negeri 8 Palu telah meningkat. Ini ditunjukkan pada peningkatan hasil belajar dimana ketuntasan belajar klasikal yang diperoleh pada siklus I yaitu $77,27 \%$ dan siklus II sebesar 90,90\% dan meningkat sebesar $14,99 \%$ dari siklus I ke siklus II. Demikian juga peningkatan daya serap klasikal dari siklus I ke siklus II, dimana daya serap klasikal pada siklus I sebesar $75,15 \%$ dan siklus II sebesar 89,09\% dengan peningkatan yang terjadi sebesar 15,64\% dari siklus I ke siklus II. Pada Siklus I, persentase ketuntasan klasikal dan daya serap klasikal belum mencapai indikator keberhasilan yang sudah diterapkan yaitu KKM sebesar 80\%. Ini disebabkan siswa belum terbiasa dengan model pembelajaran yang diterapkan. Dari hasil pekerjaan siswa juga terlihat masih banyak yang keliru dalam penggunaan rumus, yang mengakibatkan siswa belum mampu memahami permasalahan dalam soal. Sedangkan Untuk Siklus II, persentase ketuntasan klasikal dan daya serap klasikal sudah mencapai indikator ketuntasan yang telah ditetapkan yaitu $80 \%$. Hal ini disebabkan karena siswa dapat mengikuti dengan baik kegiatan proses pembelajaran Thinking Aloud Pair Problem Solving (TAPPS) sehingga dapat meningkatkan hasil belajar siswa.

Berdasarkan uraian di atas penerapan model pembelajaran Thinking Aloud Pair Problem Solving (TAPPS) memiliki kelemahan diantaranya alokasi waktu tahap pembelajaran tidak efisien, siswa belum mampu mengkomunikasikan solusi yang diperoleh disertai penggunaan rumus, dalam kelompok belajar siswa masih kesulitan membangun kerja sama yang lebih solid, dan siswa yang aktif dalam menyampaikan hasil pekerjaannya hanya beberapa siswa saja. Selain itu, model pembelajaran TAPPS memberikan dampak positif yaitu dapat meningkatkan hasil belajar siswa dalam materi usaha dan energi. Dimana siswa dapat merumuskan masalah sendiri sehingga dapat memecahkan masalah yang ada dan proses pembelajaran berfokus pada siswa. Hal ini dapat dilihat dari analisis kuantitatif telah memenuhi indikator keberhasilan yang telah ditetapkan untuk tuntas individu $70 \%$ dan tuntas klasikal $80 \%$ serta daya serap klasikal minimal 80\%. Dengan demikian dapat dikatakan bahwa penerapan model pembelajaran Thinking Aloud Pair Problem Solving (TAPPS) dapat 
meningkatkan hasil belajar fisika pada siswa kelas XI IPA SMA Negeri 8 Palu.

\section{KESIMPULAN DAN SARAN}

\section{Kesimpulan}

Berdasarkan hasil analisis data dan pembahasan dapat disimpulkan bahwa penerapan model pembelajaran Thinking Aloud Pair Problem Solving (TAPPS) dapat meningkatkan hasil belajar fisika siswa kelas XI IPA SMA Negeri 8 Palu. Peningkatan hasil belajar masing-masing adalah untuk aktifitas guru $7,29 \%$ dan aktifitas siswa sebesar $6,53 \%$ dari siklus I ke siklus II. Untuk hasil belajar siswa ketuntasan belajar klasikal terjadi peningkatan sebesar 14,99\% dari siklus I ke siklus II. Demikian juga untuk daya serap klasikal meningkat sebesar $15,64 \%$ dari siklus I ke siklus II. Pada siklus II hasil belajar siswa sudah memenuhi indikator ketuntasan belajar klasikal sebesar $80 \%$.

\section{Saran}

Kepada guru maupun calon guru yang ingin menerapkan model pembelajarn Thinking Aloud Pair Problem Solving (TAPPS di sarankan :

1) Harus memperhatikan siswa yang berpasangan dan mengefektifkan waktu selama pembelajaran.

2) Dalam memilih model pembelajaran yang akan diterapkan, guru hendaknya menggunakan model pembelajaran yang dapat merangsang perkembangan berfikir siswa dalam memecahkan masalah.

\section{DAFTAR PUSTAKA}

[1] Anita, 2007. Jurnal Penelitian Pendidikan IPA, Model Pembelajaran Thinking Aloud pair Problem Solving (TAPPS). Bandung : Program Studi IPA Sekolah Pascasarjana Universitas Pendidikan Indonesia.

[2] Depdiknas, 2003. Penelitian Tindakan Kelas. Jakarta: Departemen Pendidikan Nasional.
ISSN 23383240

[3] Kyungmoon Jeon. 2005. Jurnal Penelitian pendidikan IPA. Pengaruh Thinking Aloud Pair Problem Solving (TAPPS) pada Siswa dalam pelaksanaan Memecahkan masalah dan Interaksi Secara Lisan: http//www.JCE.DivChed.org

[4] Stice, J. E. 1987. Teaching Problem Solving tersedia:

(hhtp://wengga4block.wordpress.com/2008/ 04/17pengertian-pendekatan 
Jurnal Pendidikan Fisika Tadulako (JPFT)

Vol. 2 No. 1

ISSN 23383240 